\title{
Virtual guide on ocular self-examination to support the self-care practice for people with HIV/aids*
}

\author{
CARTILHA VIRTUAL SOBRE O AUTOEXAME OCULAR PARA APOIO À PRÁTICA DO \\ AUTOCUIDADO PARA PESSOAS COM HIVIAIDS
}

\section{CARTILLA VIRTUAL EN EL AUTO-EXAMEN PARA APOYAR A LOS OJOS A LA PRÁCTICA DE AUTOEXAMEN PARA PERSONAS COM VIH/SIDA}

\section{Maria Alzete de Lima ${ }^{1}$, Lorita Marlena Freitag Pagliuca², Jennara Candido do Nascimento², Joselany Áfio Caetano}

\begin{abstract}
The objective was to describe the process of development of a virtual guide on ocular self-examination for people with HIV/aids. The methodological proposal followed the five steps recommmended by Falkembach: analysis and planning, modeling, implementation, evaluation and distribution. The adequacy of the printed version to the virtual required the construction of a tutorial video, adding illustrative photos for viewing possible ocular changes and interactive tool demonstrating the examination result to the user. In the first material assessment, we diagnosed failures in the layout, thus commands were replaced, unified, rearranged in an easy viewing and adequacy of language. It is possible to promote the approximation of users with prevention methods in the ocular health area through a virtual guide, contributing to develop skills and disseminate self-examination.
\end{abstract}

\section{RESUMO}

Objetivou-se descrever processo de desenvolvimento da cartilha virtual sobre autoexame ocular para pessoas com HIV/aids. A proposta metodológica seguiu as cinco etapas preconizadas por Falkembach: análise e planejamento, modelagem, implementação, avaliação e distribuição. A adequação da versão impressa para virtual requereu a construção de um vídeo tutorial, agregação de fotos ilustrativas para visualização de possíveis alterações oculares e ferramenta de interatividade com demonstração do resultado do exame ao usuário. Na avaliação inicial do material, foram diagnosticadas falhas no layout. Assim, comandos foram recolocados, unificados, dispostos em local de fácil visualização e foi feita a adequação da linguagem. Considera-se possível promover aproximação do usuário com métodos de prevenção na área da saúde ocular por meio de cartilha virtual, contribuindo para desenvolvimento de habilidades e divulgação do autoexame.

DESCRITORES
Educação em saúde
Tecnologia educacional
Autoexame
HIV
Saúde ocular
Enfermagem

\section{DESCRITORES} \\ Enfermagem
}

\section{RESUMEN}

El objetivo fue describir la preparación de una cartilla virtual acerca del autoexamen ocular para personas con VIH/Sida. La metodología siguió los cinco pasos preconizados por Falkembach: análisis y planificación, modelaje, implementación, evaluación y distribución. La adecuación de la versión impresa para la virtual requirió la construcción de un video tutorial, la adición de fotografías ilustrativas para visualización de posibles alteraciones oculares y una herramienta interactiva con demostración del resultado del examen para el usuario. En la evaluación inicial del material, se diagnosticaron las primeras fallas en el diseño, así, los comandos fueron reemplazados, unificados, dispuestos en local para fácil visualización y se realizó la adecuación del lenguaje. Es posible promover la proximidad del usuario con métodos de prevención en el área de la salud ocular a través de la cartilla virtual, contribuyendo en el desarrollo de capacidades y difusión del autoexamen.

DESCRIPTORES
Educación en salud
Tecnología educacional
Autoexamen
VIH
Salud ocular
Enfermería

\author{
DESCRIPTORS \\ Health education \\ Educational technology \\ Self-examination \\ HIV \\ Eye health \\ Nursing
}

*Extracted from dissertation "Evaluation of a virtual guide on ocular self-examination for people with HIV/aids", Nursing Graduate Program, Federal University of Ceara, 2011. ${ }^{1}$ PhD candidate, Nursing Graduate Program, Federal University of Ceara. Assistant professor, Federal University of Piaui. Fortaleza, CE, Brazil. alzetelima@yahoo.com.br 2 Tenure Professor, Federal University of Ceara, Fortaleza, CE, Brazil. ${ }^{3}$ PhD candidate, Nursing Graduate Program, Federal University of Ceara, Fortaleza, CE, Brazil. 


\section{INTRODUCTION}

Promotion of eye health of individuals and collective integrate actions developed as part of the health system in Brazil. The growing number of individuals that present vision loss due to avoidable causes of blindness, in addition to those with low vision, reinforces the need for development of effective ways of screening and expanding access of population to consultation with an ophthalmologist and access to support services to conduct examinations, surgical interventions or rehabilitation.

However, ocular care needs mechanisms of continuity and systematization of investments ${ }^{(1)}$. Study conducted on the prevalence of use of eye care services in the past five years showed that from the total number of people interviewed, $34 \%$ did not undergo ophthalmologic consultation. The main reasons were: low financial conditions $(29 \%)$, lack of time (25\%) and indifference (19\%). Among people seeking care, consultations were held either through health plans provided in partnership with companies or even the state or private health plan (42\%), private consultation (23\%) consultations on optical stores (18\%) and public services $(17 \%)^{(2)}$.

The importance of this discussion is based on findings that indicate that disorders affecting vision can be attributed to the natural aging process, but there are ocular disorders triggered by pathological processes of infectious and noninfectious order, such as glaucoma, cataracts, uncorrected refractive errors and diabetic retinopathy ${ }^{(3)}$.

The ophthalmologic disorders that cause visual impairment, low vision and blindness, result not only in a decrease in quality of life, occupational, economic, social and psychological restrictions, but also in inability to work, representing an onerous burden on the individual and society. Thus, early diagnosis is important, since the lack of proper decision can determine a permanent deficit. Preventive actions have great impact on health.

In addition, there are more vulnerable groups to the development of visual problems, such as people living with HIV/aids. About $50-75 \%$ of these people develop some eye complication, most triggered by opportunistic infections and neoplasms, as a direct result of immunosuppression.

We observe, therefore, the need to ensure the extension of care beyond clinics and hospitals units, being necessary the emphasis on educational activities, with the introduction of lightweight technologies, such as brochures, booklets and manuals about the care of the eyes, through the inclusion of information about the implementation of self-care in the context of HIV/aids. It is recommended the performance of ocular self-examination that is characterized as secondary prevention without cost, safe and easily applied in large populations.

In this light, we realized the need for the development and validation of a guide on the ocular self-examination ${ }^{(4)}$.
The Guide gives advice on the performance of self-examination of the eyes by means of simple information identifying eye problems. It contains description of the technique for assessing visual acuity (near and far), external ocular structures, the visual field (peripheral vision and central vision) and eye movement. These steps aim to identify possible changes, such as reduced visual acuity, injuries, visual field loss, strabismus, diplopia, redness, among others.

Although only an ophthalmologist can accurately diagnose an ocular problem, other professionals, such as nurses, can work in screening and empowering the population to the early identification of changes. The performance of eye self-examination alert to the existence of signs of ocular involvement that require consultation with the ophthalmologist.

In an attempt to expand the population's access to eye care, a virtual guide on eye self-exam was developed and validated ${ }^{(5)}$. Its preparation comes from the high incidence of eye problems, from the lack of resources for mass production of printed material and their distribution in the health care services in the country, reinforced the need for availability on the internet. So now, there are even higher chances by the population and health professionals to use this feature, increasing the scope of the guide as the access to technology grows.

Countless possibilities of computer use in education, especially to sensitize the user to health education in the area of ocular health, stimulated the development of the guide for the virtual environment. This research aims to describe the development process of the virtual guide on ocular self-examination.

\section{METHOD}

Study of virtual guide educational material development, which considers that the elaboration of an educational hypermedia must follow the steps of analysis and planning, modeling, implementation, evaluation and maintenance ${ }^{(6)}$. In the first step, we used a guide for ocular self-examination $^{(4)}$ in which the target audience was already defined, people living with HIV/aids, the topic to be addressed, ocular health, as well as the objectives and the content to be developed, ocular self-examination. However, adaptation for internet use was necessary, considering the theoretical assumptions about distance education.

To achieve the materialization of this study, human resources and material; also financial resources from CAPES and CNPq were necessary, besides a Laboratory on Health Communication, through its physical and technological infrastructure, including a recording studio.

We opted to compose teams for its preparation, the first was the pedagogical team, composed by the authors of the printed guide and the researcher, followed by the
Virtual guide on ocular self-examination to support the self-care practice for people with HIV/aids Lima MA, Pagliuca LMF, Nascimento JC, Caetano JA 
technical team, composed of members of the Research group and Production of Interactive Environments and Learning Objects (PROATIVA), a masters in computer science, responsible for the digitization of media, and graphic design. Additionally, there was the participation of an actor and a technical specialist in filming, editing and programming.

For the modeling step, the pedagogical and design team worked, and they were responsible for drafting an instructional script, containing the initial idea of the object, the activities, the target audience for which the material was developed for (people with HIV/aids with basic knowledge on computer use and internet access) and content, and the objectives to be achieved with the use of the material. The graphic design team was responsible for developing the visual identity and the virtual educational material interfaces, based on our instructional proposal. The development process was established after the teams composition.

In the implementation phase, the project was approved by the modeling team and the programming and digitization of media and texts, as well as adequacy of the requirements of the software used. Material resources correspond to the hardware, software and Flash software.

In the evaluation phase, the texts were revised and adapted to self-instruction use, passing through media test and the necessary corrections on the text content and navigation. In the final phase of the educational material, validation was performed by six expert judges in the area of health education and distance education technologies.

The material was previously validated by content judges ${ }^{(4)}$. We sought to assess, at this time, the pedagogical and technical aspects of the guide. Inclusion criteria to compose the panel of judges were: work in the areas of distance health education and education technologies, have scientific production in these areas and obtain a minimum score in the sum of scores greater than or equal to 4.0 point ${ }^{(7)}$.

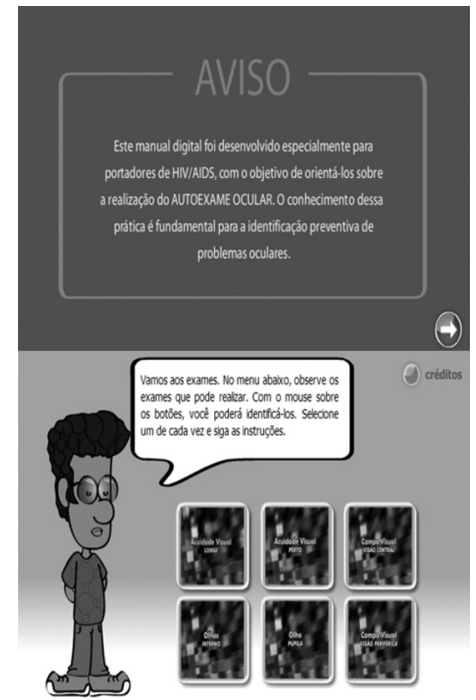

Figure 1 - Demonstration of the warning screen prior to the menu containing the exams.
Data collection was conducted through a structured script inspired by instruments of similar studies ${ }^{(8-9)}$. We used a Likert scale of four points (1 - Fully adequate; 2 - Adequate with changes; 3 - Inadequate; 4 - Not applicable). The instrument sought to evaluate the importance of content to the target audience, the contribution of technology, the encouragement of learning, the design of the material and its suitability for the virtual environment, the presentation of technology, attractiveness and ability to attract the user interest to continue browsing the site. Subjective analyzes were synthesized and organized, gathering the contributions of judges from each item evaluated.

The study was approved by the Ethics Committee in Research of the Federal University of Ceara - UFC, under protocol number 309/09. As part of the documentation, we elaborated the Consent Form (CF). Participants were informed about the study objectives, procedures, risks and benefits. Anonymity was assured and the judges who evaluated the technical aspects were denominated as T1, T2, T3 and those who evaluated the pedagogical aspects, P1, P2, P3.

\section{RESULTS}

The virtual guide is a self-instructive educational material for teaching ocular self-examination for people living with HIV/aids and have basic computer knowledge. It consists in the evaluation of the visual acuity from far/near, eye structures, eye movement, peripheral and central vision. Always before the description of the examination to be performed by the user, we oriented about the materials that would be needed for its performance. It is also possible to observe a warning screen about the necessity of hand washing and maintaining the use of glasses at the exam. These procedures are described in text format, we made available a video tutorial that demonstrates how to perform step by step (Figures 1 and 2).

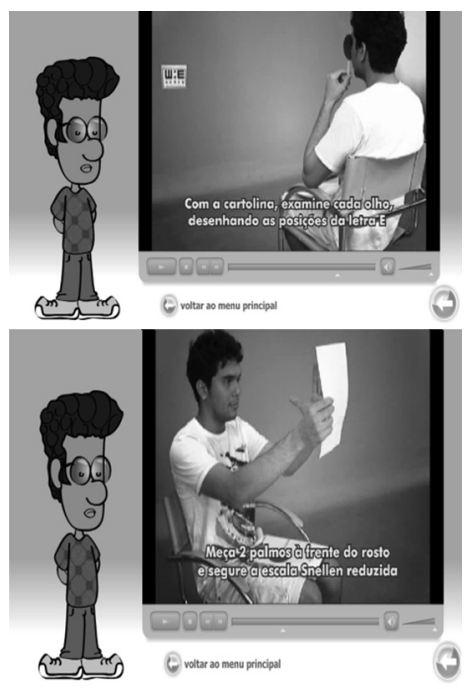

Figure 2 - Virtual educational material demonstrating the selfexamination technique in a tutorial video. 
All six judges participants of the study were nurses, aged between 28 and 59 years, with only one male. All of them were professors of Federal Universities of South and Southeast regions of Brazil. Training time ranged from 11 to 33 years and they were divided into two groups according to their specialty, three were responsible for evaluating the pedagogical aspect, and three for evaluating the technical aspects.

\section{Evaluation of the judges on the technical aspects}

With regard to access speed, the judge T1 warned that the homepage, which states the name of the virtual guide, changes quickly to the next screen, the warning. Considering important recommendations to the user, it was suggested to make it longer. So it was reformulated so that to the user would have the command, allowing them the freedom to take exams in the way they consider appropriate, ensuring their autonomy and increasing their level of interest in using the material. The speed of change of the screens was directly proportional to the need for reading and assimilation of user commands, unlike the initial version, in which it was not permitted to interfere in time to return the screens.

Table 1 - Judges opinion about the items related to the speed and agility in access to the virtual educational material and page design - Fortaleza, CE, Brazil, 2011

\begin{tabular}{|c|c|c|c|}
\hline Item & T1 & $\mathbf{T 2}$ & T3 \\
\hline Loading speed of the homepage & FA & FA & FA \\
\hline Loading speed of remaining pages & FA & FA & FA \\
\hline Downloading speed of visual assessment tables & FA & FA & FA \\
\hline $\begin{array}{l}\text { The homepage present an attractive design that } \\
\text { induces the user to navigate the website. }\end{array}$ & FA & FA & FA \\
\hline $\begin{array}{l}\text { The homepage present an attractive design that } \\
\text { induces users to access technology. }\end{array}$ & FA & FA & FA \\
\hline $\begin{array}{l}\text { The homepage presents a clear design and } \\
\text { capable enough to be handled successfully by } \\
\text { the target audience. }\end{array}$ & FA & FA & FA \\
\hline
\end{tabular}

In judges evaluation on the design there was agreement on the adequacy of educational material to which it recommends as criteria for presentation of learning objects. In the specifications of the screens, judge T1 warned us about the need to guide the reading Table in the examination of visual acuity for distance, which is available for printing on the print button. This item was inadvertently forgotten. It was also identified problems in downloading the Amsler grid, but this was promptly solved.

There was consensus on the usability, dealing with user ease in navigating the pages and corresponding contents, it was considered fully adequate by the judges. The ease of navigation from page to page, section to section, or a link to another, the link access to technology are clearly defined and its goal is to be easily identified. Additionally, it was suggested the inclusion of a link to return to the software homepage.
Table 2 - Judges opinion about the items related to the usability in pages structure and presentation of virtual learning material Fortaleza, CE, Brazil, 2011

\begin{tabular}{|c|c|c|c|}
\hline Item & T1 & T2 & T3 \\
\hline $\begin{array}{l}\text { The virtual learning material is organized in a } \\
\text { clear and logical manner in order to facilitate } \\
\text { the location of technologies. }\end{array}$ & FA & FA & FA \\
\hline $\begin{array}{l}\text { It offers all the necessary information prior to } \\
\text { access to technologies. }\end{array}$ & FA & FA & FA \\
\hline $\begin{array}{l}\text { Information is clearly displayed and organized } \\
\text { in order to be easily understood by the target } \\
\text { audience. }\end{array}$ & FA & FA & FA \\
\hline $\begin{array}{l}\text { The content of the information presented in the } \\
\text { links is appropriate for users. }\end{array}$ & FA & FA & FA \\
\hline The graphic design of the pages favors learning. & FA & FA & FA \\
\hline $\begin{array}{l}\text { The presentation of the technology contributes } \\
\text { to learning or attention of the user. }\end{array}$ & FA & FA & FA \\
\hline $\begin{array}{l}\text { The information provided is reliable and promote } \\
\text { the realization of ocular self-examination. }\end{array}$ & FA & FA & FA \\
\hline The information presented is updated. & FA & FA & FA \\
\hline $\begin{array}{l}\text { The material promotes appropriate feedback to } \\
\text { the user. }\end{array}$ & FA & FA & FA \\
\hline
\end{tabular}

FA: Fully Adequate, AC: Adequate with changes. T1: Technical Judge 1, T2: Technical Judge 2, T3: Technical Judge 3.

As for the structure and presentation about the way to introduce the technology, involving overall organization, structure, presentation strategy, coherence and sufficiency. The review was unanimous that the educational material is fully appropriate.

Very good, I congratulate the clarity and presentation of the texts, easy reading (T2).

This is an easy reading and fast material, easy to access and understand its information (T1).

I didn't identify difficulties related to the use of technology (T3).

These statements show the relevance of the material. The evaluators emphasize the clarity of information and ease of use. With respect to reliability, which deals with essentials items to point the quality of the tools used, they stated:

\begin{abstract}
After the exams performance central visual-field vision it does not show written on the icons the word examination as in other examinations (T1).

In the pupil examination it does not appear the difference (pupillary reaction), which can hinder the observation of the change. At the presentation in front of the mirror, it is not clearly presented, a demonstration of this phenomenon in cartoon may be necessary (T2).
\end{abstract}

Given these appointments, the suggestions of technical judges were successfully accepted, with drawing an animation demonstrating the pupillary reaction, illustrating the phenomenon being observed by the user. All
Virtual guide on ocular self-examination to support the self-care practice for people with HIV/aids Lima MA, Pagliuca LMF, Nascimento JC, Caetano JA 
judges considered the virtual educational material reliable and high quality.

\section{Evaluation of judges in relation to pedagogical aspects}

Table 3 - Judges opinion related to the speed and agility in access to virtual educational material and page design - Fortaleza, CE, Brazil, 2011

\begin{tabular}{|c|c|c|c|}
\hline Item & P1 & $\mathbf{P 2}$ & $\mathbf{P 3}$ \\
\hline $\begin{array}{l}\text { Can emphasize the importance of content that is } \\
\text { addressed among people living with HIV/AIDS. }\end{array}$ & $\mathrm{AC}$ & I & $\mathrm{AC}$ \\
\hline Arouses interest and curiosity. & $\mathrm{AC}$ & $\mathrm{AC}$ & $\mathrm{AC}$ \\
\hline $\begin{array}{l}\text { Is appropriate and it can be used as health edu- } \\
\text { cation for access to distance. }\end{array}$ & $\mathrm{AC}$ & $\mathrm{AC}$ & $\mathrm{AC}$ \\
\hline Contributes and stimulates learning. & NA & $\mathrm{AC}$ & $\mathrm{AC}$ \\
\hline $\begin{array}{l}\text { Encourages autonomy, as a method of self- } \\
\text { instruction. }\end{array}$ & $\mathrm{AC}$ & $\mathrm{AC}$ & FA \\
\hline The runtime is adequate. & FA & FA & FA \\
\hline $\begin{array}{l}\text { The technology is suitable for the target audience } \\
\text { (according to age and expertise of computer use). }\end{array}$ & FA & FA & FA \\
\hline $\begin{array}{l}\text { The technology does not reflect any kind of } \\
\text { discrimination or prejudice. }\end{array}$ & $\mathrm{AC}$ & $\mathrm{AC}$ & FA \\
\hline The language is interactive. & $\mathrm{AC}$ & $\mathrm{AC}$ & FA \\
\hline There is clear information. & $\mathrm{AC}$ & $\mathrm{AC}$ & FA \\
\hline $\begin{array}{l}\text { The graphics and videos represent the content in } \\
\text { an understandable way. }\end{array}$ & FA & FA & FA \\
\hline
\end{tabular}

The only item considered inappropriate with respect to the ability to emphasize the importance of content addressed among people living with HIV/aids. The argument of the Judge $\mathrm{P} 2$ indicates that the material does not provide information about the importance of being aware of the ocular changes in this specific population.

Regarding the appropriateness of the material and the possibility to be used as distance education access, the judge refers to the fact that there are several factors that interfere the learning process, and not only the provision of accessible materials. The stimulus to learning will depend on the context in which the material and the motivations of the user group will be inserted to access it.

About the item relating to the encouragement of autonomy, as a method of self-instruction, Judge P2 raised the need to stimulate the search for more information. The judge made suggestions:

More expected results could be included, such as actual benefits and what are the risks of someone suffering with these problems. This would encourage users to engage in make testing (P1)

According to the judge, this action would encourage users to engage in making the tests. With respect to items about the educational material and discrimination or prejudice, judge P2 questioned the fact that the character in the guide had brown skin.

Will users relate HIV/aids eye problems to those who are black? We could use various ethnic groups in the material, or at least show their presence. We could keep the main character as black, but we could insert dialogues between him and others, providing other information (P2).

Regarding the characteristics linked to language and interactivity, P2 evaluator noted that terms like main menu, mouse, click on the buttons cannot be part of the vocabulary of general users. In this case, due to the necessity of its use, it is suggested to offer a glossary of terms or replace them with universal terms. This justifies such guidance because, when faced with different nomenclature, the user gives up.

Overall, the judges made mention of virtual learning material for ocular self-examination as a tool that addresses relevant topic, easy to carry and no problems in connecting to the internet network.

\section{DISCUSSION}

The assumptions that guided the development of this virtual educational material are based on recent evidence that computers and technologies are seen as the future of education and as a powerful tool to promote the development of learning ${ }^{(10)}$.

The virtual educational material characterized by didactic content with the use of multimedia and interactivity, associated to resources of informatics and communication technologies. These virtual resources are developed following an integrated planning to the learning process, outlined in a pedagogical perspective ${ }^{(11)}$.

Patients respond better and are more likely to adopt new behaviors when the approach occurs in a trust and closeness relationship with their reality. The technology scenario promotes increasingly better information, making it a challenging solution to encourage the development of individual and holistic care for complex clinical challenges. The online learning is implemented to maximize the results of health interventions ${ }^{(12)}$.

The use of computers as a tool in the teaching and learning process has occurred more significantly in institutions. Groups of researchers have been investigating best practices in online education in nursing, considering the use of technology, educational practices, student support and outcomes ${ }^{(13)}$. There is a correlation between educational practice and patient satisfaction, to make the process more autonomous.

The materials for remote access favor aspects such as the inclusion, opportune interactivity, collective knowledge production, accessibility, self-learning of 
the individual who accesses the content, besides that, it also enables both personal and professional advantage in continuous education, being considered by several authors as a means of effective teaching and learning of quality ${ }^{(14)}$.

It is known that the education strategies with direct or distance approach are equally effective in providing health information and awareness among customers. However, distance education requires more investment, especially in healthcare. The paradigm of disease treatment can be extended to the management of well-being, which focuses on the maintenance and improvement of health care based on individual(15).

Recent studies show that well made materials and information easy to understand improve patient knowledge and satisfaction and promote the development of actions that influence the pattern of health and promote decision making, also contribute to reducing the use of services and health costs ${ }^{(14)}$.

However, difficulties can be discussed, such as the need to adapt to the semi-technics procedures of virtual environment in order to comply with the scientific findings that prove its effectiveness. The search for this adjustment is justified by corroborate the changes in the new educational paradigm and the emergence of new technologies like computer and the Internet, which opened the door to the use of resources that go beyond the traditional view and merely discursive methods in the teaching and learning process ${ }^{(15)}$.

With consulting support, it was possible to promote improved quality of a virtual guide. Among the recommendations, we highlight the additional orientations on location of the material to be printed prior to assessment of visual acuity, assigning the command to move the screens to the user wishes, including the animation demonstrating pupillary response that must be observed by the user to take the examination, confirmation of bidirectional function of commands, allowing the back and forth between pages as needed by the user, and the inclusion of a glossary of technical terms.

Creating a video tutorial applied to the description of procedures brought additional benefits in terms of providing information. It justifies the recent recommendations that video clearly overcome traditional didactic material(15), because it transmits information through the senses, hearing and sight. Thus, it allows patients to use virtual technology insertion of a realworld perspective.

Additional tools were used in the preparation and establishment of new concepts, such as the practice of ocular self-examination for people living with HIV/aids, who are more susceptible to eye disorders. With the new proposal of ocular self-care, we project to achieve an education that make individuals aware of their responsibility.
With the release of the virtual guide, we intend to increase the demand for health services for the early detection of eye disorders from susceptible public. With the introduction of new procedures, we expect greater adherence to self-assessment with a view to decision-making, through learning and recognition of the need for specialized services.

The virtual guide offers information systematically, it has characteristics of accessibility and reusability. It is expected that the unlimited access may provide greater practical proposal, like the printed educational material, question to be investigated in future studies.

\section{CONCLUSION}

The development of virtual guide on ocular self-examination, the result of accumulated experience from previous studies in research group on eye health had the purpose to increase the promotion of ocular health and ensure a product with technical quality and accessible for public use.

The virtual guide proved to be adequate to support people living with HIV/aids in identifying ocular disorders, in addition to stimulating the development of skills and critical awareness to significantly contribute to their health by allowing them the opportunity to seek specialized care in the early stages of ocular disease before changes become irreversible and evolve into vision loss.

After making the adjustments suggested by the judges' evaluation, a wide dissemination of the material will be necessary in educational actions developed within primary care, in partnership with universities and research centers to develop research in the area of ocular health.

There is need for further studies to assess the impact of the virtual guide use for eye self-examination in the daily practice of individuals and groups, aiming at the improvement of the material, reducing barriers, facilitating the achievement of the following steps. The validation of educational materials, specifically in the area of Nursing, increases the chances of developing a quality material, adapted to the needs of users of technology.

The limitations of the study indicate the use of technical terms related to the virtual environment, and the need to make downloads of the scales used during the process of visual acuity assessment (near and far). These may require more effort from the user and can be demotivating to the self-examination performance. Another barrier to the use of virtual and printed versions of the virtual guide is the existence of a large number of illiterate people in Brazil. Other strategies are necessary to those people so that they may perform an ocular self-examination, since they are also at risk for the development of visual disorders.
Virtual guide on ocular self-examination to support the self-care practice for people with HIV/aids Lima MA, Pagliuca LMF, Nascimento JC, Caetano JA 


\section{REFERENCES}

1. Taleb A, Ávila M, Moreira H. As condições oftalmológicas de saúde ocular no Brasil. São Paulo: Conselho Brasileiro de Oftlamologia; 2009.

2. Castagno VD, Fassa AG, Silva MC, Carret MLV. Carência de atenção à saúde ocular no setor público: um estudo de base populacional. Cad Saúde Pública. 2009;25(10):2260-72.

3. World Health Organization (WHO). Action Plan for the Prevention of Avoidable Blindness and Visual Impairment: 20092013. Geneva: WHO; 2010.

4. Caetano JA, Pagliuca LMF. Cartilha auto-exame ocular para portadores do HIV/AIDs como tecnologia emancipatória: relato de experiência. Rev Eletr Enferm [Internet]. 2006 [citado 2013 set. 21];8(2):241-9. Disponível em: http://www.revistas. ufg.br/index.php/fen/article/view/7039

5. Nascimento JC, Lima MA, Almeida PC, Pagliuca LMF, Caetano JA. Assessment of the virtual guide on eye self-examination in the context of HIV/AIDS. Acta Paul Enferm. 2012;25(n. spe1):87-93.

6. Falkembach GAM. Concepção e desenvolvimento de material educativo digital. Novas Tecnol Educ [Internet]. 2005 [citado 2013 set. 21];3(1). Disponível em: http://seer.dev.ufrgs.br/index.php/renote/article/viewFile/13742/7970

7. Fehring R. Methods to validate nursing diagnostics. Heart Lung. 1987;16(6):625-9.

8. Oliveira PMP, Pagliuca LMF. Assessment of an educational technology in the string literature about breastfeeding. Rev Esc Enferm USP [Internet]. 2013 [cited 2013 Sept 21];47(1):205-12. Available from: http://www.scielo.br/pdf/ reeusp/v47n1/en_a26v47n1.pdf
9. Cezario KG, Pagliuca LMF. Tecnologia assistiva em saúde para cegos: enfoque na prevenção de drogas. Esc Anna Nery Rev Enferm. 2007;11(4):677-81.

10. Keser H, Özcan D. Current trends in educational technologies studies presented in World Conferences on Educational Sciences. Soc Behav Sci. 2011;15:3989-98.

11. Mashhadi VZ, Kargozari MR. Influences of digital class rooms on education. Comput Sci. 2011;3:1178-83.

12. Kaufman N. Using health information technology to prevent and treat diabetes. Diabetes Technol Ter. 2013;15 Suppl 1:S60-74.

13. Cogo ALP, Pedro ENR, Silva APSS, Specht AM. Avaliação de mapas conceituais elaborados por estudantes de enfermagem com o apoio de software. Texto Contexto Enferm. 2009;18(3):482-8.

14. Pommier J, Guevel MR, Jourdan D. Evaluation of health promotion in schools: a realistic evaluation approach using mixed methods. BMC Public Health. 2010;10:43.

15. Holtzblatt M, Tschakert N. Expanding your accounting classroom with digital video technology. J Account Educ. 2011(23):100-21.

\section{Support}

Funded by CNPQ e CAPES 